\title{
Suspect Technologies: Forensic Testing of Asylum Seekers at the UK Border
}

\author{
Richard Tutton (Lancaster University), Christine Hauskeller (Exeter \\ University) and Steve Sturdy (University of Edinburgh)
}

Paper accepted for publication in Ethnic and Racial Studies (out in 2014).

\begin{abstract}
The entanglement of border control technologies and immigration policies and practices with discourses of race, national identity and belonging has long been a focus of scholarly interest. In this paper we discuss the Human Provenance Pilot Project (HPPP), the aim of which was to evaluate the utility of genetic and isotope testing to corroborate asylum seekers' accounts of their nationality. We subject the HPPP to a detailed socio-technical analysis, highlighting how technologies, practices and modes of thought travelled from the policing context to the asylum context, illuminating the unspoken prejudices that made that transfer possible, and reflecting on implications of the HPPP for academic research, policy advice and the asylum system.
\end{abstract}




\section{Suspect Technologies: Forensic Testing of Asylum Seekers at the UK Border}

\section{Introduction}

In this paper we examine the Human Provenance Pilot Project (HPPP) conducted in 2009-10 by the UK Border Agency (UKBA). This project aimed to evaluate the utility of genetic and isotope testing to corroborate asylum seekers' accounts of their nationality. When it gained public attention in September 2009, the HPPP was heavily criticised by leading scientists, journalists, and parliamentarians, who argued that the use of genetic and isotope tests to ascertain nationality was scientifically indefensible as well as ethically objectionable. In the face of this concerted criticism, the UKBA decided to suspend the HPPP before reinstating it as a shorter three-month study, rather than the twelve-month pilot as originally planned. Whereas initially the UKBA had intended to include the results of genetic ancestry and isotope analysis in the assessment of live asylum applications, in the new study such tests would now be conducted for research purposes only, and the results would be anonymized so that they would not impact on asylum decisions (UKBA 2009). The trial ended on 31 March 2010. As late as October 2010, the UKBA was still promising to publish a review of the HPPP. However, in response to a Freedom of Information request by one of the authors (RT), the UKBA eventually stated that:

Following the conclusion of the pilot, a decision was taken within the UK Border Agency not to take forward DNA/Isotope testing for country of origin identification purposes in the foreseeable future. On the basis of this decision, it was agreed that resources would not be devoted to carrying out an evaluation of the pilot at this point in time. If a decision to resume Familial DNA or Country of Origin testing is taken in the future, further consideration will be given to the scientific, legal and ethical basis on which it would operate. The Home Office would engage with relevant experts to address any concerns that may be raised regarding the use of this technique. (Martin 2011)

The UKBA response also revealed that in the course of the HPPP, 198 familial relationship tests over 76 family groups were carried out, with 38 individuals tested as part of the 'country of origin' element (Martin 2011).

One might be tempted to dismiss the HPPP as just another of the operational embarrassments that have dogged the UKBA since it was formed in 2008, and that led in March 2013 to the Home Secretary's decision to abolish the Agency. However, the fact that the UKBA and Home Office persisted with the HPPP in spite of apparently devastating criticism from the scientific community, and did not rule out the possibility of reintroducing something similar in future, raises broader questions concerning public policy on the use of technology for border control. The UKBA's interest in adopting new molecular technologies to test nationality claims comes at a time of more general change in the ideology and practice of border control in the UK 
and more widely. Researchers have pointed out how increasingly exclusionary immigration policies, and an increasingly close integration of immigration with criminal law, have tended towards de facto criminalisation of asylum seekers in both Europe and North America (Arat-Koc 1999, Miller 2003, Silveira Gorski 2008, Shuster 2011). In the UK, official and popular attitudes to those who request sanctuary have become dominated by a hermeneutic of suspicion. Public and policy discourses portray asylum seekers as mostly 'bogus' refugees seeking admission to the country for economic, not humanitarian reasons. Seen in this context, the UKBA's turn to genetic and isotope tests as a means of ascertaining nationality acquires a quite specific set of meanings, that tell us much about how the Agency and the Home Office regard asylum seekers.

The entanglement of border control technologies and immigration policies and practices with discourses of race, national identity and belonging has long been a focus of scholarly interest (Fox et al. 2012). But the use of genetic and isotope tests adds further layers of prejudice and suspicion to the mix. For one thing, the technologies trialled in the HPPP originated in forensic practices of criminal investigation, from where they were imported directly into the work of border control. The HPPP thus represents a further expression of the more general inclination on the part of the UKBA to criminalise asylum applicants, in this case by subjecting them to biometric and other identification practices more usually employed in a criminal setting. Second, in the context of the HPPP, asylum seekers were accorded even fewer rights than would normally be granted to criminals. The effectiveness of genetic and isotope testing to determine place of origin has yet to be proven even in a criminal investigation context; its adoption into border control was thus purely experimental. Yet the UKBA decided to enrol vulnerable people as experimental subjects under conditions which effectively denied them the right to decide freely whether to submit to the tests. This is entirely contrary to the normal tenets of biomedical ethics, which apply to criminals as much as to other human subjects. Third, by adopting such technologies, the Border Agency sought to bypass asylum seekers' testimonies of persecution and of why and how they came into the UK, replacing them with impersonal methods of assessing eligibility. This silencing only compounded the loss of identity, dignity and power of self-determination already suffered by refugees.

The HPPP thus reveals a remarkable willingness on the part of the UKBA to treat asylum seekers as criminal suspects, suspend their basic human rights, subject them to unethical forms of human experimentation, and silence their personal narratives until chemical tests can prove them innocent of the presumption of lying and nationality fraud. In part, these problems may be obscured by the aura of objectivity that commonly attaches to new molecular technologies. In this paper, we therefore subject the HPPP to a detailed socio-technical analysis, highlighting how technologies, practices and modes of thought travelled from the policing context to the asylum context, illuminating the unspoken prejudices that made that transfer possible, and reflecting on the implications of the case of the HPPP for academic research, policy advice and the asylum system.

\section{The development of border control in the UK}


In the wake of the terror attacks in the US on 11 September 2001, border controls of North American and European countries have been intensified in order to counter the threats from international terrorism. In 2007, the British Government reorganized its border control services and formed the UK Border Agency. This agency initiated a UK $£ 1.2$ billion 'e-borders' programme to accelerate adoption of biometric and other new technologies in order to further enhance border control. The British Government claimed that it was 'delivering the biggest shake-up of border security and the immigration system in a generation' (Cabinet Office 2009: 97). Nick VaughanWilliams (2010) argues that identity management has become central to how the British Government conceptualizes border control. In its 2007 White Paper on border control, the Government stated that 'managing identity is fundamental' to effective border security and that the aim of the UKBA is to 'fix people's identities at the earliest point practicable' (Anon 2007).

The UKBA's announcement of the HPPP in September 2009 belongs in this context of increased investment in and technologization of border control. National identity has become vitally important in assessing whether someone claiming the right to asylum is a legitimate refugee or an economic migrant. Since at least the early 2000 , border agencies focused increasingly on the possibility that economic migrants might pose as citizens of particular countries in order to gain access to Britain as recognized refugees. Justifying its investment in the HPPP, the UKBA indicated that a 'significant percentage of asylum applicants' might be engaging in 'nationality-swapping', in particular applicants from the East African region. Kenyan nationals were allegedly seeking to pass themselves off as Somalis. The HPPP focused specifically on asylum applicants from that area to determine whether isotope and DNA analysis could help to 'identify at the outset of the asylum process those who are claiming under a false nationality' (UKBA 2009).

Since the early 1990s, the legitimacy of those applying for asylum has been a hot political issue and a perennial interest of right-wing tabloid journalism using an aggressive derogatory rhetoric. Greenslade argues that the British tabloid press came increasingly to depict asylum seekers

as a separate minority group. They have been made into scapegoats for a variety of society's current ills [...] To this end, editors have sought to forge a unity of viewpoint between the indigenous white population and second and third generation Afro-Caribbean and Asian immigrants in opposition to asylumseekers, of whatever race or creed. (Greenslade, 2005: 6)

In a context where immigration policy has become increasingly concerned with distinguishing 'deserving' from 'undeserving' migrants, the status of asylum seekers has become particularly fraught (Flynn 2005, Sales 2005). There have been various well-publicized interventions to 'crack down' on 'bogus asylum seekers' by both Conservative and Labour administrations, whose measures have included reducing the benefits given to asylum applicants and a firmer approach to the detention and deportation of rejected applicants (Campbell, 2013). New policies were established including the detention of asylum applicants in detention centres if their claim is considered to be decided quickly. Meanwhile, as Zetter and Pearl observe: 'Tighter 
pre-entry deterrent measures have been matched, in-country, by a persecutory regime of welfare disentitlement and social exclusion for those who have managed to gain access [...] destitution amongst asylum seekers, as a result, has risen enormously since major legislative change in 1996' (Zetter and Pearl 2000). Official statistics show that the number of asylum applications to Britain has declined significantly over the last ten years, due in part we might assume to the effectiveness of some of these interventions in projecting a view of Britain as inaccessible and inhospitable to refugees. However, the debate about 'bogus asylum seekers' has not lost force in public and policy discourses in a time of economic crisis and austerity.

\section{Seeking Asylum}

Along with other signatories to the 1951 Geneva Convention on the Status of Refugees, Great Britain is bound to provide a system to assess asylum claims from individuals, without discrimination as to religion, nationality, political opinion or membership of a particular social group. Britain is also a signatory to the 1950 European Convention on Human Rights and the European Union Asylum Qualification Directive, which also provides the legal basis on which individuals can make asylum claims. Yet the policies implemented by British and other European governments to restrict migration and asylum have altered the situation of migrants and refugees (Geddes 2003; Flynn 2005). Developments in EU immigration policy since the early 1990s have tended to limit the rights of refugees to enter the EU in order to seek asylum, and the policy that visa and entry documents should be applied for in the relevant embassy in the home country prior to travel, rather than upon arrival in the UK, places additional barriers in the way of those who face indifference, hostility or persecution from the authorities in their home country (Guild 2010). Asylum seekers are increasingly suspected of illegitimately claiming political persecution (Lynn and Lea 2003) and individuals in need of refuge face bureaucratic procedures that make it more difficult to leave one's country and reach a safe destination.

One result of bureaucratisation and the tightening of immigration rules in Europe has been to increase asylum seekers' reliance on clandestine methods of entry (Schuster 2011). Those seeking asylum in Europe have become increasingly dependent on professional traffickers who are paid for providing transportation and often forged passports and identity documents. Traffickers are 'experts' on immigration policies, suitable travel routes and border control practice and often choose the country of arrival according to recent policy developments and practicalities. This leads to the separation of families or friendship networks. Asylum seekers report in interviews that they feel a lack of control about which country they go to and how. This weakens their confidence and their chances of integration into a new culture and society (Healey 2006; Korac 2003). Moreover, under UK law, illegal entry into the country is now a criminal act. Consequently, use of the expertise and infrastructure provided by traffickers in order to arrive in a safe country further taints perceptions of migrants' integrity (Koser 2000).

In 2007, the Home Office introduced a new process for dealing with asylum claims, called the New Asylum Model whereby a UKBA staff member assumes the role of case 
owner and is responsible for all the decisions taken on an asylum application until the person is granted or denied permission to stay. The case owner will conduct interviews with the applicant. A first interview aims to record details about how the applicant came to arrive in Britain and whether there was a relevant previous application for asylum either in Britain or another EU member state. A second interview, called the 'asylum interview', follows in which the applicant has the opportunity to give an account of why she or he wishes to apply for asylum. The overwhelming majority of asylum applications are rejected at this stage. The applicant then has the right of appeal and to be heard by an independent immigration judge. As Anthony Good (2009) argues, the outcome of this process largely depends on the credibility of the applicant's own testimony regarding her or his history and reasons for arrival in Britain to claim asylum:

When presenting their claims, most asylum applicants cannot produce documentary corroboration of their ill-treatment, and certainly cannot call as witnesses those who have persecuted them. Asylum decisions are therefore heavily dependent upon assessments of the credibility of their accounts, presented to the Home Office and the courts mainly in the forms of asylum interview transcripts and witness statements. (Good 2009:1)

In a context where it is increasingly assumed that a high proportion of applicants do not tell the truth about their reasons for seeking admission to the country, the process is heavily weighted towards finding reasons to doubt the applicant's testimony and reject the application.

Given the uncertainties involved in assessing asylum applicants' testimony, for some time now the UKBA - along with border agencies in other countries - has sought other methods to inform decision making. A key method, in this respect, is the technique of language analysis. Since the early 200os, the UKBA has sub-contracted commercial firms to analyse the speech of asylum applicants, with the aim of determining whether they actually come from the country they claim (Campbell, 2013). Despite fundamental doubts about the validity of language analysis as a test of nationality, since 2008, language analysis has been applied several thousand times to asylum applicants, particularly those presenting as Somalian refugees (Campbell 2013). Language analysis can be seen as a 'technology of identification' aimed at establishing aspects of an applicant's identity without relying on their personal testimony.

Against this background, the HPPP is an attempt to develop and implement additional technologies of identification that aim to establish nationality independently of asylum applicants' testimony and documentary evidence. The HPPP involved two such technologies: genetic testing for bio-geographical origins and isotope testing. These technologies were trialled specifically as an additional test to support language testing, which has been subject to legal challenge (Campbell 2013). Genetic ancestry testing and isotope analysis were to be undertaken in cases where personal testimony and language analysis led UKBA officers to suspect that an individual who claimed to be from Somalia might actually be from another country. We now turn to discuss three particular areas of concern that arise from the HPPP which have wider implications. 


\section{Technological Border Crossings}

One important issue that the case of the HPPP highlights is the uncritical way in which technologies that had yet to establish their validity and utility in the context of forensic science and criminal investigation, were nonetheless adopted into the asylum context - initially, at least, on the assumption that they could be useful in evaluating 'live' asylum applications. In this section, we focus on the background to how genetic ancestry testing and isotope testing came to be adopted by the leaders of the HPPP.

We wish to emphasize how the genetic tests employed in the HPPP differ from other genetic technologies of identification. In the immigration context, DNA testing is regularly used to determine biological relationships between individuals. This wellestablished and well-validated test involves looking at the degree of similarity between the DNA of two individuals to determine whether they are closely related, for instance as parent-child or siblings. Likewise, in forensic applications, routine DNA identification is based on simple matching of DNA profiles obtained from scene-ofcrime DNA traces with those from suspects. In contrast, the genetic tests for ancestry and geographical origins trialled in the HPPP were significantly more complex and tenuous.

Genetic ancestry tests emerged in the late 1990s out of decades of basic research on population genetics. They utilize knowledge of how genetic variations arise through mutation and accumulate within more or less isolated populations, which thus come to embody distinctive combinations of gene variants. By analysing particular genetic variants present in an individual's DNA, it may therefore be possible to infer, with a reasonable degree of probability, that certain of that individual's ancestors were members of a particular bio-geographical population. However, there are very clear constraints on the precision and certainty with which such inferences can be drawn. The ability to trace ancestry to any particular population depends upon how precisely that population has been characterised in genetic terms: ancestry tracing is only as good as the genetic reference databases on which it draws. The construction of such databases is informed by prior assumptions about what counts as a population, and bio-geographic identities are thus inevitably coloured by ethnic/racial and geopolitical presuppositions. Moreover, because DNA variants are passed on through generations, it is difficult to infer just how recently an individual's ancestors lived in a particular region. Consequently, a bio-geographic origin test may show that a particular individual has shared ancestors with members of a population that now lives predominantly in a particular location, but says little about that individual's own recent place of residence, still less about her or his nationality.

Despite these constraints, however, genetic testing for ancestry and geographical origins has come to be widely used, not just as a research tool by scientists interested in historical population movements, but also as a consumer service (Shriver and Kittles, 2004). One important market is among private users interested in tracing their recent genealogical and ancestral history. The idea that genetic testing can help to throw light on an individual's 'roots' has been widely popularised in the media. The experiences of individuals who have undergone such testing to discover more about their family histories and geographical origins provide compelling stories of personal 
identity and social history, and many such stories have featured in newspapers and magazine articles (Harmon 2007) and television programmes (such as Motherland: A Genetic Journey, broadcast February 2003 on BBC television: see BBC 2003). As a result, hundreds of thousands of consumers have bought genetic ancestry tests over the past ten years (Wolinsky, 2006: 1073).

The marketing, uptake and effects of these tests have in turn been examined by social scientists. Some re-emphasise their scientific untrustworthiness, noting for instance that commercial genetic tests for bio-geographical origins often do not take account of the large population movements that have taken place across Africa in the past 200300 years, and urging that this may have implications for the truth of the origin and identity stories that consumers build around such tests (Royal et al., 2010, Lee et al., 2009, Scully et al. 2013). Some suggest that such limitations are unimportant, since genetic ancestry testing is little more than a harmless recreational indulgence. Thus US bioethicist Henry Greely concludes that genetic genealogy is 'interesting but arguably not very important ... genealogy .. [is] rarely of real significance' (Greely, 2008: 229). This has been very much the orthodox view: regulators and policy advisors have given little serious consideration to genetic ancestry testing, on the assumption that the ethical issues at stake are far less critical than those related to medical genetics (e.g. Human Genetics Commission 2003).

However, a growing number of social scientists argue that, despite its scientific and technical limitations, the dissemination of genetic ancestry testing into popular culture has the potential to effect far-reaching changes in ideas of identity, belonging, history and race (Bolnick et al., 2007, Elliott and Brodwin, 2002, Skinner, 2006, Nelson, 2008, Tutton, 2004, Nash, 2004). In particular, they point to instances where genetic ancestry testing is used not just for recreational purposes, but for the express purpose of identifying membership of particular socio-political groups. For instance, such testing has been employed by Native Americans in the US to determine tribal membership in ways that can exclude individuals who have traditionally been part of such tribes (Tallbear, 2008, Beckenhauer, 2003). In such cases, DNA testing is being used to redraw the boundaries around certain social and political identities, sometimes with profound implications for how individuals and groups think about themselves and for the life choices available to them. Meanwhile, forensic agencies have also taken an active interest in genetic ancestry tests as a possible means of identifying or eliminating suspects in criminal investigations. Notably, in Britain, the Forensic Science Service has looked into the geographical distribution of particular Y chromosome variants, and their association with particular surnames, as a means of using scene-of-crime samples to narrow down the range of likely suspects (Vince 2006).

While genetic ancestry testing concentrates on tracing the genes of ancestors in contemporary human bodies, isotope testing is based on the way that the different environments in which an individual lives may leave distinctive traces in her or his body. The proportions of different isotopes of various chemical elements present in the environment vary from one locality to another. These elements are ingested in food and drinking water and are incorporated, over time, into body tissues. Consequently, assuming that a person consumes local food, water and air, the 
proportions of different isotopes present in her or his tissues will mirror those in the place where s/he lives. Moreover, because different tissues are laid down at different times in a person's life, they embody a record of the person's diet, and her or his movements over time. Adult teeth, for instance, are largely laid down between the ages of four and twenty, and may thus provide an indication of where a person lived as a child or young adult. Bone tissues, by contrast, are replaced over a period of several years, while hair and nails are replaced within a matter of months, so provide an indication of a person's habitation or consumption within more recent time frames.

It should be noted that, since both the number of naturally occurring isotopes and the range of possible variation is small, many different places in the world share similar isotope profiles. Consequently, isotope testing cannot be used to specify a unique location but may be useful as a way of eliminating options from a range of possible locations. These limitations are reflected in the way that archaeologists have used isotope testing to reconstruct the life course and migration of neolithic and early mediaeval individuals from well-preserved skeletons (Evans et al. 2006, Budd et al. 2004): the confidence with which such reconstructions may be made is greatly aided by the fact that population movements at that time generally occurred over relatively small distances, thus reducing the range of possible places of origin, and that people consumed almost exclusively local food and water.

By the early 20oos, isotope testing was also becoming incorporated into forensic techniques for tracing the origins of biological and chemical substances. Law enforcement agencies in North America and Europe formed networks with academic centres, forensic research laboratories and commercial laboratories to develop ways of applying isotope science to various aspects of law enforcement. Isotope analysis is now routinely used to authenticate the origins of certain imported foodstuffs such as honey. More importantly for security purposes, in 1999 the Forensic Explosives Laboratory (FEL) at Fort Halstead in Kent, England, was funded by the British Home Office to examine the utility of isotope ratios in the forensic analysis of explosives, with a view to tracing their movement through international terrorist networks (Doyle, 2002).

Crucially for the story of the HPPP, genetic ancestry and isotope testing were used together for forensic purposes in the early 2000 in a rather unusual police investigation that became known as the Thames torso case. In September 2001, the Metropolitan Police began investigating a dismembered body of a young boy found in the river Thames in London. The unknown victim came to be known as 'Adam'. Within a few months, the Police came to focus on the theory that Adam was the victim of a ritualistic killing, which the British media repeatedly reported as an 'African ritual murder' (Sanders, 2003: 58). Although a number of Africanist anthropologists consulted by the Metropolitan Police contested this framing of what happened to the boy, arguing a lack of evidence to support this account, the detectives pursued this line of inquiry (Ranger, 2007, Sanders, 2003). As well as visiting Nigeria and South Africa, they employed the services of population geneticists and geochemists to help them determine the boy's ancestry and place of origin. Mitochondrial DNA analysis indicated that he was probably of West African origin, while analysis of the strontium isotopes in his bones was consistent with him having 
grown up in a 'small area in north-west Africa, probably a rural area near the city of Benin in south-western Nigeria' (in Ranger 2007: 272). As a result of a witness coming forward, police now believe they have identified the boy and have spoken to relatives still living in Nigeria (Quinn, 2011). Though the perpetrators have never been found, the case generated considerable media interest and much of the original investigation was documented by a film crew and shown on British television.

A direct link can be drawn between this case and the HPPP. The detective in charge of the Thames torso investigation was Detective Inspector Will O'Reilly. He is credited with being responsible both for proposing the HPPP and for securing its funding from the British Foreign and Commonwealth Office (FCO) under its Returns and Reintegration Fund, with 'full Ministerial support' (Douglas, 2009). On retiring from the Metropolitan Police he became the project manager of the HPPP, and - or so it is claimed- went on to assist in the construction of 'isotopic and ancestral DNA databases for the forensic use of law enforcement agencies worldwide' (Anon 2012). It would appear that the HPPP was directly inspired by O'Reilly's experience of using these new and still relatively untested technologies of identification in the Adam torso case. We now consider whether these new technologies can appropriately be transferred to the assessment of asylum applications..

\section{Substituting Biology for Nationality}

Recent years have seen a massive intensification in the use of new technologies of identity - including biometrics and networked information technology as well as language analysis - not just for evaluating the credibility of asylum applicants, but for routine purposes of border control. Such technologies are concerned with identity, not as experienced by individuals, but as assigned by impersonal, suspicious and often hostile agencies. As Louise Amoore (2011) has argued, they diminish the agency of all who cross international borders, by depriving them of their right to tell their own stories (see also Feldman 2012). The use of biometric and linguistic technologies shifts the evidence from the applicant's personal narrative of persecution to seemingly objective means of assessing certain aspects of identity. However, such technologies of identity do not simply offer more objective means of confirming or disconfirming conventional identity claims. They actually redefine the social categories of identity on which immigration and asylum decisions are based. Thus, genetic family relationship testing replaces the social category of kinship with the biological category of genetic relatedness; as other observers have noted, since biological relatedness does not necessarily map onto kinship, for instance where children are adopted, this may do violence to family relationships and cause renewed distress to those seeking asylum (Heinemann \& Lemke 2012). The HPPP went even further in seeking to employ biological categories of ancestry and life history as a proxy for the social category of nationality. Criticism of the HPPP has focused primarily on the viability of this substitution.

With regard to isotope testing, critics pointed out that archaeologists and forensic investigators are typically able to base their inferences about individuals' origins and movements on measurements from a range of tissues, including teeth and bone as well as hair and fingernails. By contrast, UKBA officials plainly could not expect to 
take tooth or bone samples from asylum applicants, so were limited to observations of hair and fingernails, which only provide information about an applicant's likely diet over the previous six months to a year. This placed very severe limits on what can be inferred from such measurements. Asylum applicants often spend protracted periods away from their home country before arriving at their country of destination. Many Somali refugees, for instance, spend years in refugee camps outside their home country, while those who resort to human trafficking networks may spend long periods being moved from one place to another before being delivered to Britain. Even where individuals come directly to Britain from their home country, their diet in the previous months could often be heavily supplemented with imported food, particularly in countries such as Somalia that receive significant quantities of food aid. All of these factors will mean that the isotopes present in asylum applicants' hair and nails may bear little relationship to those found in their home country. In consequence, it is difficult to see how isotope analysis could provide meaningful information about the origins of asylum applicants subjected to the HPPP. It might, however, provide evidence consistent with an individual having recently spent time in another country outside their country of origin - which the UKBA typically sees as sufficient reason to reject an asylum application, since it assumes the applicant can safely be returned to that other country.

Moreover, the use of isotope testing to indicate whether a person's biological make-up is consistent with them having spent time in a particular region depends on having sufficiently detailed information about the distribution of the relevant environmental isotopes across that region. Such data as exist for Somalia are very sketchy, while the situation there makes it unlikely that accurate mapping will be undertaken in the foreseeable future. Similar objections have been made to the use of genetic ancestry testing under the HPPP. Critics pointed out that there is little detailed information about the genetics of Somali populations; the present political situation effectively prohibits the kind of research that would be necessary to generate such information. Even if such research were possible, significant and often chaotic population movements prompted by the political situation would likely render the resulting data unreliable in a relatively short time. The UKBA sought to get around these problems by compiling information on the genetics of various Kenyan populations, on the grounds that the majority of 'bogus' Somali asylum seekers were thought to come from Kenya - but without proper knowledge of the genetic similarities, differences and overlaps between Kenyan and Somali populations, such information was useless.

This leads to another, even more fundamental issue, namely that biological information about population genetics or environmental circumstances has no necessary relationship to the social categories of national identity and citizenship. As the journal Nature puts it: "the idea that genetic variability follows man-made national boundaries is absurd" (Nature 2009). Exactly the same point can be made about language analysis (Campbell 2013). On the one hand, national borders have often been drawn in ways that cut across existing population groupings - as for instance in Eastern Africa, where ethnic Somalis are found on both sides of the border that divides Somalia from Kenya. On the other hand, national borders rarely represent a complete barrier to human migration and relations, and such migrations may be especially large 
in war-torn areas like the Horn of Africa. In sum, genetic testing, and information about probable place of residence provide no guide to nationality.

\section{Asylum Seekers as Experimental Subjects}

If the use of genetic and isotope tests as proxies for nationality was scientifically dubious, the trialling of such tests in live asylum cases was ethically indefensible. Normally, the use of genetic technologies of investigation and identity is heavily circumscribed by ethical safeguards to protect privacy and individual integrity; and this is particularly the case when those technologies are unproven, and are being employed purely for research purposes. We might expect that such safeguards would be applied with especial rigour when dealing with vulnerable individuals in a crisis situation. However, while the UKBA did gesture in the direction of research ethics procedures, those procedures were far too weak to provide genuine protection to the individual asylum applicants who passed through the HPPP. The Agency specified that individuals whom officials wanted to subject to genetic ancestry and isotope testing should be told about the tests, given the option of refusing consent, and assured that refusal would not prejudice the outcome of their asylum application - a procedure that they regarded as 'informed consent'. However, applicants were also to be told that a refusal would be recorded, and would be made known to the UKBA officers and appeal judges responsible for the final decision (UKBA 2009). Under such circumstances, it is unlikely that an applicant would be reassured that a refusal would not influence assessment. The procedures fell far short of ethical expectations which include free and informed consent to a genetic test; for vulnerable individuals anxious to satisfy the demands of an inhospitable asylum system, the pressure to give consent must have been considerable.

This de facto suspension of normal research ethics procedures is all the more striking when we realise that there was no good reason why research into isotope and genetic ancestry testing need even have been conducted on actual asylum applicants. The declared purpose of the trial was to assess whether such tests were effective in determining the real country of origin of asylum applicants claiming to come from Somalia. But that purpose could equally well have been met by looking not at individuals who were currently seeking asylum, but at those who had already been granted it. Indeed, such a trial would arguably have been more scientifically conclusive, since the fact that the subjects had already satisfied the normal asylum requirements would effectively serve as a control for the effectiveness of the technologies being evaluated. It would also have been more ethically sound, since those tested, having already been granted asylum, might be seen as having less to lose from refusing to participate in the experiment.

In fact, the UKBA appears to have given little thought to such ethical issues when designing the HPPP. Rather, it seems to have taken it for granted that asylum applicants are legitimate subjects of investigation, whose special vulnerabilities can effectively be ignored. If anything, the turn to genetic ancestry testing and isotope analysis, like the adoption of language analysis, serves to exploit and compound those vulnerabilities by diminishing asylum applicants' agency in the process of legitimising their own case for asylum. Applicants' ability to tell their own story about their 
personal experiences of threat and persecution, as understood by the 1951 Geneva Convention, becomes secondary to tests administered and controlled by border agencies. This only adds to the loss of agency and control that they already suffer, not only as a result of having to flee their home country, but also, in many cases, from having to place themselves in the hands of human traffickers, with all that may entail in terms of being given a false identity and entering a world of dubious legality (Healey 2006; Koser 2000). For those fleeing persecution in their own country, that deprivation may entail incalculable risks to health, life, and social status, while rejection of their application and repatriation to their country of origin could lead to imprisonment, injury or even death.

\section{Conclusion}

In this article we have discussed a widely criticized pilot project which the UKBA undertook in 2010 to trial the use of genetic ancestry and isotope testing in asylum application cases. While the UKBA states that it has no plans to develop these techniques in the 'foreseeable future', the possibility remains that its successor agency or another immigration agency in another country may take up such technologies at a future time.

We argue that the HPPP was indicative of a broader set of trends by which technologies, practices, and modes of thought from the context of criminal investigation have come to shape the asylum system. The sociologists Robin Williams and Paul Johnson have argued persuasively that the establishment and use by UK police of the forensic National DNA Database should be seen as part of a larger paradigm shift in policing: from a criminal justice paradigm, premised on a concern to deliver justice equally to all citizens, to a crime management paradigm, concerned rather with identifying and managing what is taken to be an inherently criminal element within society (Williams and Johnson 2008). According to Williams and Johnson, the routine use of technologies of identity like the National DNA Database has been a vital element in realising the crime management paradigm, by providing an effective means of both identifying and incriminating that criminal element.

By the same token, we might see the HPPP as part of a similar shift in asylum procedures: from a humanitarian paradigm motivated by a concern to provide shelter for the victims of human rights abuses, to a border control paradigm concerned with restricting the movement of suspicious would-be immigrants. In the border control case as in the crime management case, new technologies of identification were adopted as a means of identifying and excluding suspect individuals from the privileges of life in respectable society. Indeed, the UKBA even anticipated that the results of the HPPP would eventually be evaluated by the Forensic Science Regulator, who is normally responsible for ensuring that forensic services meet appropriate standards of scientific quality (Vorhaus 2009). Given all this, the HPPP looked very much like a further step towards the de facto criminalisation of asylum applicants. In this respect, it is notable that, faced with concerted criticism of the scientific viability of the HPPP, the UKBA was moved to declare that it had at least proved to be an effective deterrent, as measured by a significant reduction in the number of asylum claims during the time it was in operation. In this presumption of guilt, as in the 
decision to subject vulnerable individuals to unethical research practices, the HPPP actually went rather further in dismissing the rights of individuals than would normally be permissible when dealing with criminal suspects.

The priorities behind the introduction of the HPPP are evident: it was motivated at least as much by a desire to exclude asylum seekers as by any concern to provide refuge to those in legitimate need. And while the HPPP may have failed to validate dubious scientific practices of border control, the political impetus behind its introduction persists. As such, the HPPP stands as a salutary warning of the ways in which supposedly objective technologies of identification are increasingly being used at international borders as a way of further disempowering the already vulnerable. While the UKBA has decided, at least for the time being, against using genetic ancestry testing and isotope analysis, the HPPP nonetheless raises a number of serious issues that we have detailed in this paper.

While some of the response from the scientific community showed a sense of surprise and indignation, against the background of the developments we have outlined above, the HPPP should perhaps not have been so unexpected. It highlights that policy advisors and social scientists need to be alert to the many ways in which new technologies - especially in the field of genetics - might be taken up. While bioethicists and social scientists have sometimes been criticised for getting ahead of the research, anticipating or speculating about social effects which may never happen, the HPPP actually shows that ethical and political vigilance - informed by just such sociotechnical anticipation - is important if such abuses are to be avoided. Wider public discussion and solid reflection in advance might have prevented the initiation of the HPPP in the first place.

\section{References}

AMOORE, L. 2011 'Data Derivatives', Theory, Culture E Society, vol. 28, no. 6, pp. 2443.

ANON 2007 'Securing the UK Border: Our Vision and Strategy for the Future'. London: Home Office.

ANON 2012 'Will O’Reilly', speaker biography, International Association of Women Police, http://www.iawp2012.org/conference/speakers.html, accessed 1 September 2013.

BBC 2003 'Long lost roots of Black Britons revealed by groundbreaking BBC TWO documentary', http://www.bbc.co.uk/pressoffice/pressreleases/stories/2003/o2_february/o5/m otherland.shtml, accessed 13 February 2013

ARAT-KOC, S. 1999 'Neo-liberalism, State Restructuring and Immigration: Changes in Canadian Policies in the 1990s', Journal of Canadian Studies, vol. 34, no. 2, pp. 31-56

BECKENHAUER, E. 2003 'Redefining race: can genetic testing provide biological proof of Indian ancestry?', Stanford Law Review, vol. 56 pp. 161-19o.

BOLNICK, D. A., et al. 2007 'The Science and Business of Genetic Ancestry Testing', Science, vol. 318, no. 5849, pp. 399-400. 
Budd, P. and Millard, A. and Chenery, C. and Lucy, S. and Roberts, C. (2004) 'Investigating population movement by stable isotope analysis : a report from Britain.', Antiquity., 78 (299). pp. 127-141.

CABINET OFFICE 2009 'The National Security Strategy of the United Kingdom: update 2009, security for the next generation'. London: The Stationary Office.

CAMPBELL, J. 2013 'Language analysis in the United Kingdom's refugee status determination system: seeing through policy claims about "expert knowledge"', Ethnic and Racial Studies, 36, No. 4, 670-69o.

DOUGLAS, M. 2009 'Letter to stakeholders: Human Provenance Pilot Project'. Croydon: UK Border Agency.

DOYLE, S. 2002 'Stable Isotope Ratio Profiling. The Challenge and the Vision', Network Developing Forensic Applications of Stable Isotope Ratio Mass Spectrometry Conference. Brands Hatch, England.

ELLIOTT, C. \& BRODWIN, P. 2002 'Identity and genetic ancestry tracing', British Medical Journal, no. 325, pp. 1469-71.

EVANS, J A, STOODLEY, N, CHENERY, C A. 2006. A strontium and oxygen isotope assessment of a possible 4th century immigrant population in a Hampshire cemetery, southern England. Journal of Archaeological Sciences, 33, 265-272

FELDMAN, G. 2012 The Migration Apparatus: Security, Labor and Policymaking in the European Union. Stanford: Stanford University Press.

FLYNN, D. 2005 'New Borders, New Management: The Dilemmas of Modern Immigration Policies', Ethnic and Racial Studies, vol. 28, no. 3, pp. 463-49o.

FOX, E., MORUSANU, L. \& SZILASSY, E. 2012 'The Racialization of the New European Migration to the UK', Sociology, vol. 46, no. 4, pp. 68o-695.

GEDDES, A. 2003 The Politics of Migration and Immigration in Europe. London: Sage.

GOOD, A. 2009 'The taking and making of asylum claims: credibility assessments in the British asylum courts', Keynote Lecture, Seeking Refuge: Caught Between Bureaucracy, Lawyers, and Public Indifference, ESRC-funded Conference, School of Oriental \& African Studies, London.

GREELY, H. T. 2008 'Genetic genealogy: genetics meets the marketplace', in KOENIG, B., LEE, S. S.-J. \& RICHARDSON, S. S. (eds) Revisiting Race in the Genomic Age. Rutgers University Press.

GREENSLADE, R. 2005 Seeking Scapegoats: The Coverage of Asylum in the UK Press. London: Institute for Public Policy Research.

GUILD, E. with BIGO, D. 2010 'The Transformation of European Border Controls', in RYAN, B. and MITSILEGAS, V. Extraterritorial Immigration Control: Legal Challenges. Leiden: Martinus Nijhoff, pp. 257-280.

HARMON, A. 2007 'Genetic Testing + Abortion = ???'. New York Times, 13 May, available online at

http://www.nytimes.com/2007/05/13/weekinreview/13harm.html, accessed 13 February 2013.

HEALEY, R. 2006 'Asylum seekers and refugees: a structuration theory analysis of their experiences in the UK', Population, Space and Place, vol. 12, no. 4, pp. 257-271.

HEINEMANN, T. \& LEMKE, T. 2012, 'Suspect Families: DNA Kinship Testing in German Immigration Policy', Sociology, DOI: 10.1177/o038038512454352.

Human Genetics Commission 2003 Genes Direct - Ensuring the effective oversight of genetic tests supplied directly to the public. London: Department of Health 
KORAC, M. 2003 'Integration and how we facilitate it: A comparative study of settlement experiences of refugees in Italy and the Netherlands', Sociology, vol. 37, no. 1, pp. 51-68.

KOSER, K. 2000 'Asylum policies, trafficking and vulnerability', International Migration, vol. 38, no. 3, pp. 91-111.

LEE, S. S.-J., et al. 2009 'The Illusive Gold Standard in Genetic Ancestry Testing', Science, vol. 325, no. 5936, pp. 38-39.

LYNN, N. \& LEA, S. 2003 'A Phantom Menace and the New Apartheid': The Social Construction of Asylum-Seekers in the United Kingdom', Discourse Society, 14, pp. 425-452.

MARTIN, D. 2011 'Response to Freedom of Information request'. London: UKBA.

MILLER, T.A. 2003 'Citizenship and severity: recent immigration reforms and the new penology', Georgetown Immigration Law Journal, vol. 17, pp. 611-6.

NASH, C. 2004 'Genetic kinship', Cultural Studies, vol. 18, no. 1, pp. 1-33.

NATURE 2009, 'Editorial: Genetics without Borders', Nature, vol. 461, p. 697

NELSON, A. 2008 'Bio Science', Social Studies of Science, vol. 38, no. 5, pp. 759-783.

QUINN, B. 2011 'Police to fly to Nigeria following new lead in Thames torso case', The Guardian. London and Manchester.

RANGER, T. 2007 'Scotland Yard in the Bush: Medicine murders, child witches, and the construction of the occult: a literature review', Africa, vol. 77, no. 2, pp. 272283.

ROYAL, C. D., et al. 2010 'Inferring Genetic Ancestry: Opportunities, Challenges, and Implications', The American Journal of Human Genetics, vol. 86, no. 5, pp. 661673.

SALES R. 2005 ' Secure Borders, Safe Haven: A Contradiction in Terms?' Ethnic and Racial Studies, vol. 28, no. 3, pp. 445-462.

SANDERS, T. 2003 'Imagining the Dark Continent: The Met, The media and the Thames torso', Cambridge Anthopology, vol. 23, no. 3, pp. 53-66.

SCHUSTER, L. 2011 'Turning Refugees into "Illegal Migrants": Afghan Asylum Seekers in Europe', Ethnic and Racial Studies, vol. 34, no. 8, pp. 1392-1407.

SHRIVER, M.D. \& KITTLES, R.A. 2004 'Genetic Ancestry and the Search for Personalized Genetic Histories', Nature Reviews Genetics, vol. 5, no. 8, pp. 611618.

SILVEIRA GORSKI, H.C., FERNANDEZ, C. \& MANAVELLA, A. 2009 'A Right-Based Approach to Migration Policies in a Context of Emergencies: "Expelling States" and Semi-Persons in the European Union'. Barcelona: University of Barcelona. Available from:

http://www.libertysecurity.org/IMG/pdf_deliverable_dic_20o8.pdf (accessed 13 February 2013).

SKINNER, D. 2006 'Racialised Futures: Biologism and the Changing Politics of Identity', Social Studies of Science, vol. 36, no. 3, pp. 459-488.

TALLBEAR, K. 2008 'Native-American-DNA.coms: In Search of Native American Race and Tribe', in KOENIG, B., LEE, S. S.-J. \& RICHARDSON, S. (eds) Revisiting Race in a Genomic Age. Piscataway: Rutgers University Press.

TUTTON, R. 2004 '"They want to know where they came from": population genetics, identity, and family genealogy', New Genetics and Society, vol. 23, no. 1, pp. 105 120. 
UKBA 2009 'Nationality Swapping - Isotope and DNA Testing (Annex B)', available online at http://www.genomicsnetwork.ac.uk/media/nationality-swappingDNA-testing.pdf, accessed 24 September 2013.

UNITED NATIONS HIGH COMMISION FOR REFUGEES 2012 'Convention Relating to the Status of Refugees', http://www2.ohchr.org/english/law/refugees.htm, accessed 13 February 2013.

VAUGHAN-WILLIAMS, N. 2010 'The UK border security continuum: virtual biopolitics and the simulation of the sovereign ban', Environment and Planning D: Society and Space, vol. 28, pp. 1071-1083.

VINCE, G. 2006 'Y chromosomes give the name away', New Science - Science in Society, http://www.newscientist.com/article/dn8757-y-chromosomes-give-thename-away.html, accessed 13 February 2013.

VORHAUS, D. 2009 The Human Provenance Project Attempts to Unring the Bell, http://www.genomicslawreport.com/index.php/tag/human-provenance-pilotproject/ (accessed 24 September 2013)

WILliAMS, R. \& JOHNSON, P. 2008 Genetic Policing: The Use of DNA in Criminal Investigations. Willan Publishing.

WOLINSKY, H. 2006 'Genetic genealogy goes global', EMBO Reports, vol. 7, no. 11, pp. 1072-1074.

ZETTER, R. \& PEARL, M. 2000 'The minority within the minority: refugee communitybased organisations in the UK and the impact of restrictionism on asylumseekers', Journal of Ethnic and Migration Studies, vol. 26, no. 4, pp. 675-697.

RICHARD TUTTON is Senior Lecturer in the Department of Sociology at Lancaster University.

ADDRESS: Department of Sociology, Lancaster University, Lancaster, LA1 4YT, UK. Email: r.tutton@lancaster.ac.uk

CHRISTINE HAUSKELLER is Senior Lecturer in the Department of Philosophy at University of Exeter.

ADDRESS: St Germans Road, Exeter EX44PJ, UK. Email: c.hauskeller@exeter.ac.uk

STEVE STURDY is Senior Lecturer in Science Technology and Innovation Studies at University of Edinburgh.

ADDRESS: Science Technology and Innovation Studies, Old Surgeons' Hall High

School Yards Edinburgh, UK. Email: S.Sturdy@ed.ac.uk 